\title{
The Effect of Customer Relationship Management (CRM) and Entrepreneurship Orientation Towards the Company Performance in Micro Small Medium Enterprises in Kediri
}

\author{
A.N. Rahmadi ${ }^{* *}$, D. Djunaedi ${ }^{2}$, N. Nurlaely ${ }^{3}$ \\ ${ }^{1,2,3}$ Faculty of Economics, University of Kadiri, Kediri, East Java Indonesia \\ *Corresponding author. Email : afifnur@unik-kediri.ac.id
}

\begin{abstract}
The purpose of this study is to determine the effect of Customer Relationship Management (CRM) and entrepreneurial orientation toward the company performance both partially and simultaneously on Micro Small and Medium Enterprises in Kediri. The population of the study is micro small and medium businesses in Kediri, while the sample of this study is 100 respondents. The sampling technique used was purposive sampling while this study was not used the total population but focused on the target. The results of the respondents' answers were only 98 respondents. Based on the results of data analysis and discussion can be concluded that the consisting of variables Customer Relationship Management (CRM) and entrepreneurial orientation variables have a partial effect on company performance in MSMEs in Kediri and the biggest effect is shown by Customer Relationship Management variables. It was found that Customer Relationship Management (CRM) and entrepreneurial orientation simultaneously have a significant effect on company performance. If all small and medium micro enterprises in Kediri apply and improve CRM and entrepreneurial orientation, there will be an increase in company performance. And this is good for the survival of the business.
\end{abstract}

Keywords: Customer Relationship Management, Entrepreneurship Orientation and Company Performance.

\section{INTRODUCTION}

Nowadays, business world is growing rapidly, every year there are many new businesses. These businesses will become competitors in two kind of business sectors. Therefore, every company must continue to adapt the changes to survive and run in business competition. In addition, many universities in Indonesia teach entrepreneurship subject, in which the emergence of entrepreneurship subject will build entrepreneurial interest for students. Based on the results of the study that student entrepreneurship interest is very high and several factors that influence student entrepreneurship interest in students are factors of innovation and creativity and the technology environment [1]. Considering that, the progress and the increasing number of customers whose are highly educated customer makes voters more critical and the products or services that will be used. Based on the resulting its product will not be enough, the company must also have a strategy to establish good and sustainable relationships for each customers [2].

Today's corporate relationships with customers have always been the main focus to continue to be maintained and enhanced by companies in addition to the products produced. Relationships with customers are not just communication. For most companies, the question is not to communicate, but what to say, to whom and how often [3]. Several previous studies have shown the influence of CRM on company performance. Stated that CRM improves organizational performance through activities 
such as increasing customer satisfaction and loyalty, cross selling products and services using word of mouth and organizational profitability through better delivery of products and services that lead to more many more benefits for the company [4]. Effective CRM implementation will affect marketing performance and financial performance accumulated as company performance [5].

Entrepreneurial orientation is characteristic at the company level because it reflects the company's behavior [6]. There is often a decrease in performance or even a business failure due to the inability to maintain a position or achieve business targets in many kinds of business. The need to continue to grow along with the development of the business world is sometimes still difficult to fulfill for some companies, especially those who are not entrepreneurial. The need for an entrepreneurial mindset to find new opportunities for businesses that provide new innovations to existing businesses [7].

Entrepreneurial-oriented companies will be stronger to survive and be able to create new strategies and innovate and take risks to seek new opportunities [8]. Companies want to improve the success of corporate enterpreneurship (corprate entrepreneurship) should be oriented enterepreuneruship [9]. In this research the formulation of the problems are as follows:

1. Does Customer Relationship Management affect company performance?

2. Does the entrepreneurial orientation affect the company's performance?

3. Are Customer Relationship Manegement and entreneurial orientation influencing the company's performance simultaneously?

\subsection{Theory Study}

\subsubsection{Customer Relationship Management (CRM)}

Customer Relationship Management (CRM) is a strategy that companies need to optimize profits by improving business strategies, [10]. The use of technology in CRM makes companies understand the desires and needs of consumers will strengthen the relationship between them. The successful implementation of CRM strategies will increase competitive advantage, [11].

\subsubsection{Orientation entrepreneurship}

Orientation entrepreneurship consists of three dimensions, namely innovation, risk taking, and proactive [12]. The study of entrepreneurial orientation is the concept of entrepreneurial management, reflecting the processes, methods, and organizational styles acting in an entrepreneurial manner [13].

Specific dimensions of entrepreneurship orientation on three dimensions, namely innovation (innovativeness), proactiveness, and risk taking, [14].
First, innovation is the willingness to introduce newness and novelty through a process of experimentation and creativity aimed at the development of new products and services as well as new processes [9]. Second, proactiveness is a prospective characteristic that is forward looking that has a foresight to look for opportunities in anticipating future requests [9]. Finally, risky courage is the willingness of the company to decide and act without a definite knowledge of possible income and possibly speculate in personal, financial and business risks [9]. Entrepreneurial orientation contributes to performance and defined as a plural measure that includes financial performance [15].

\subsubsection{Company Performance}

Behavior as a variable of performance (process), output and results (value added or impact), [16]. [17] propose an integrated and integrated model that explains the relationship between the company's entrepreneurial behavior and the environment, strategy, internal company factors and company performance.

Measurement can be done using two factors, namely; (1) measure the performance that can be done, (2) performance measurement that is relevant to companies that are always ready at all times, [18]. Performance can measure financial performance, customer satisfaction, internal processes and growth and growth, [19]. Business questionnaires can be used from; level of sales, sales costs, assets owned, brand image and fixed assets owned by company, [20]. Some experts reveal that the measure of corporate performance that is most often used in empirical research is financial performance (Financial performance), operational performance (operationalperformance), and a market-based performance (market- based performance), [21].

\subsubsection{Hypothesis}

The hypothesis in this study is :

H1 : Customer Relationship Management influences company performance.

$\mathrm{H} 2$ : Entrepreneurial orientation influences company performance.

H3 : Customer Relationship Management and entrepreneurial orientation simultaneously affect the company's performance.

\subsection{Research Methodology}

The population in this study are micro small and medium businesses in the Kediri, the number of MSMEs in Kediri according to data from the Office of Cooperatives and MSMEs in East Java totaling 29,306. While the sample of this study is 100 UMKM taken by sampling theory from Slovin, with an error rate of $10 \%$. The sampling technique used was purposive sampling where this study was not carried out by the entire population but focused on the target. 
Purposive sampling means that sampling is limited to certain types of people who can provide the desired information [22].

\subsection{Result And Discussion}

This research data was obtained and collected by distributing questionnaires directly to respondents who were successfully met. This questionnaire was obtained by the researcher by meeting the respondent directly and giving a questionnaire to the respondents. $\mathrm{H}$ acyl respondents who deserve only 98 respondents. Most of the types of businesses that are respondents here are the processing, trade, transportation and services industries. This survey was conducted in July - October 2019.

\subsubsection{Validity and Reliabel Test}

Validity test results in this study indicate that the results of the questionnaire with indicators of Customer Relationship Management (CRM), entrepreneurial orientation and company performance are valid, while the test is reliable itas shows all the variables have variable has a coefficient of a $1 p h$ a sizeable ie above 0.60 so it can be said of all the concept of measurement of each variable of the questionnaire is realibel so for the next items on each variable concept worthy used as a measuring instrument .

In processing data using multiple linear regression, several steps are taken to find the relationship between the independent variable and the dependent variable through the relationship betweenCustomer Relationship Management (CRM) variables and entrepreneurial orientation towards company performance, where this calculation uses the help of the SPSS program, it is obtained the multiple regression coefficient which appears an equation

$$
\mathrm{Y}=0.872+0.436 \mathrm{X} 1+0.174 \mathrm{X} 2+\mathrm{e} .
$$

From the above equation, it can be gotten the result, the constant $\alpha=0.872$ means that if there is no change in CRM and entrepreneurial orientation, then the company's performance will increase by 0.872 units. A CRM ika rose as much as one unit, the company's performance will increase by 0.436 units. Next if the entrepreneurial orientation increases by one unit, the company's performancewill increase by 0,174 units.

Based on the results of the $t$ test above, it can be concluded that all variables consisting of CRM variables and entrepreneurial orientation variables have a partial effect on the company's performancein MSMEs in Kediri. And the biggest effect is shown by Customer Relationship Management variables. This shows that $\mathrm{H} 1$ and $\mathrm{H} 2$ is accepted. This research was supported from previous research where the results of his research show that CRM has an influence on company performance [23]. It can be concluded that the application of CRM good will be able to improve the company's performance, both from financial and operational performance. In addition this research is supported by previous research from [22] research where the results of his research prove that entrepreneurial orientation has a direct and positive influence on company performance. This means that the stronger the entrepreneurial orientation that is owned by the company, it will improve the company's performance. To test the next hypothesis, namely $\mathrm{H} 3$, it can be seen that the significance of the $F$ test for the independent variable is smaller than the significant $\alpha$ (0.05). This shows that $\mathrm{H} 3$ is accepted. So the two independent variables consisting of CRM and entrepreneurial orientation have a simultaneous influence on company performance.

\section{CONCLUSION}

Based on the results of the discussion it can be concluded:

1. From the results of this study Customer Relationship Management (CRM) has an influence on company performance. The more small and medium micro enterprises in Kediri implement CRM, the company's performance will increase.

2. The influence of entrepreneurial orientation on company performance. The owner of a small and medium sized micro-business understands and enhances entrepreneurial orientation so that the company's performance will also increase.

3. The results show the CRM and orientation simultaneously many enterpreneurship got a significant effect on the performance of the company. If all small and medium micro enterprises in Kediri apply and improve CRM and entrepreneurial orientation, there will be an increase in company performance. And this is good for the business survival

\section{Recommendations}

Based on the results of the research, discussion and limitations of research, the following suggestions can be put forward:

1. It is expected to increase the role of universities in Kediri, to assist small and medium micro enterprises. Because all this time small and medium micro businesses have little understanding of Customer Relationship Management (CRM) and entrepreneurial orientation. If this variable is truly understood and improved it will help improve the performance of small and medium micro enterprises in Kediri

2. Kediri's Government is expected to be the bridge of the small and medium micro enterprises in marketing a product outside the area of Kediri, because it is expected that products from small and 
medium micro businesses in Kediri will be well known and developed in the outer regions of Kediri. So that the performance in the company will increase and the opening of employment again for the Kediri.

3. It is expected that there will be additional variables other than CRM and entrepreneurial orientation that will be able to influence the company's performance. And maybe this research is also carried out in other region in order to find new findings that will help the development of small and medium micro enterprises

\section{REFERENCES}

[1] A. N. Rahmadi and B. Heryanto, "Analisis Faktor-Faktor Yang Mempengaruhi Minat Berwirausaha Pada Mahasiswa Program Studi Manajemen Fakultas Ekonomi Universitas Kadiri," J. Ekonika, vol. 1, no. 2, pp. 153-169, 2016.

[2] B. Yosua, S. Suharyono, and E. Yulianto, "Pengaruh Customer Relationship Management (CRM) Terhadap Kepuasan Dan Loyalitas Pelanggan (Survei pada Pelanggan GraPARI Telkomsel di Kota Malang)," J. Adm. Bisnis, vol. 46, no. 1, 2017.

[3] P. Kotler and G. Armstrong, "Prinsip-Prinsip PEMASARAN," pp. 1-63, 2001.

[4] A. M. Gathaiga, "Customer Relationship Management As a Strategy To Gain Competitive Advantage in the Banking Industry a Case Study of Kenya Commercial Bank in Kenya By United States International University," 2013.

[5] Capgemini, "Customer Relationship Management Next Generation ( CRM NG )," Dharma Ekon., vol. 18, no. 33, pp. 1-12, 2013.

[6] J. G. Covin and D. P. Slevin, "Strategic management of small firms in hostile and benign enviroments," Strateg. Manag. J., vol. 10, no. 1, pp. 75-87, 1989.

[7] R. G. McGrath and C. MacMillan, "The Entrepreneurial Mindset.”pp. 1-5, 2000.

[8] H. P. Witjaksono, "Analisis Orientasi Kewirausahaan dan Sumber Daya Internal Perusahaan Terhadap Kinerja Melalui Keunggulan Bersaing ( Studi pada Usaha Mikro Kecil dan Menengah Furniture Kabupaten Jepara )," J. Bisnis Strateg., vol. 23, no. 1, pp. 83-110, 2014.

[9] G. G. Dess and G. T. Lumpkin, "The Role of Entrepreneurial Orientation in Stimulating Effectiev Corporate Entrepreneurship," Acad. Manag. Exec., vol. 19, no. 1, p. 147, 2005.

[10] A. P. S. U. Siregar, "Pengaruh Customer Relationship Management Dan Kualitas Strategi
Bisnis Meningkatkan Kinerja Unit," J. Sains Pemasar. Indones., vol. XV, no. 3, pp. 193-205, 2016.

[11] M. Alipour and M. H. Mohammadi, "The Effect Of Customer Relationship Management (CRM) On Achieving Competitive Advantage Of Manufacturing Tractor," Glob. J. Manag. Bus. Res., vol. 11, no. 5, pp. 27-36, 2011.

[12] J. Frishammar and S. Åke Hörte, "The Role of Market Orientation and Entrepreneurial Orientation for New Product Development Performance in Manufacturing Firms," Technol. Anal. Strateg. Manag., vol. 19, no. 6, pp. 765788, 2007.

[13] H. H. Stevenson and J. C. Jarillo, "A paradigm of entrepreneurship: Entrepreneurial management," Entrep. Concepts, Theory Perspect., vol. 11, pp. 155-170, 2007.

[14] D. Miller, "The Correlates of Entrepreneurship in Three Types of Firms," Manage. Sci., vol. 29, no. 7, pp. 770-791, 1983.

[15] J. Wiklund, "The Sustainability of the Entrepreneurial Orientation- Performance Relationship," no. 1992, pp. 37-48, 1999.

[16] J. I. Mwita, "Performance management model: A systems-based approach to public service quality," Int. J. Public Sect. Manag., vol. 13, no. 1, pp. 19-37, 2000.

[17] J. G. Covin and D. P. Slevin, "A Conceptual Model of Entrepreneuship as Firm Behavior.” pp. 7-25, 1991.

[18] A. Neely, "The performance measurment revolution: why now and what next?," Int. J. Oper. Prod. Manag., vol. 19, no. 2, pp. 205-228, 1999.

[19] A. H. C. Tsang, A. K. S. Jardine, and H. Kolodny, "Measuring maintenance performance: A holistic approach," Int. J. Oper. Prod. Manag., vol. 19, no. 7, pp. 691-715, 1999.

[20] U. S. Bititci, Ut. Turner, and C. Begemann, "Dynamics of performance measurement systems," Int. J. Oper. Prod. Manag., vol. 20, no. 6, pp. 692-704, 2000.

[21] A. A. Jahanshahi, M. Rezaei, K. Nawaser, V. Ranjbar, and B. K. P. Pitamber, "Analyzing the effects of electronic commerce on organizational performance: Evidence from small and medium enterprises," African J. Bus. Manag., vol. 6, no. 22, pp. 6486-6496, 2012.

[22] S. Uma, Metodologi Penelitian untuk Bisnis, 4th ed. Jakarta: Salemba Empat, 2006.

[23] D. P. Indah and Devie, "Analisa Pengaruh Knowledge Management Terhadap Keunggulan Bersaing dan Kinerja Perusahaan," Bus. Account. Rev., vol. 1, no. 2, pp. 161-171, 2013. 